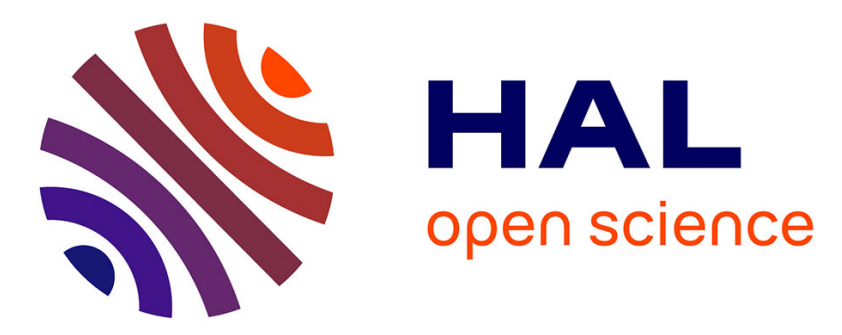

\title{
Fishing for survival: The forgotten slaves of Tromelin Island (Indian Ocean)
}

\author{
Philippe Béarez, Laurie Bouffandeau
}

\section{To cite this version:}

Philippe Béarez, Laurie Bouffandeau. Fishing for survival: The forgotten slaves of Tromelin Island (Indian Ocean). International Journal of Osteoarchaeology, 2019, 29 (3), pp.487-498. 10.1002/oa.2763 . hal-02401215

\section{HAL Id: hal-02401215 \\ https://hal.science/hal-02401215}

Submitted on 20 Dec 2020

HAL is a multi-disciplinary open access archive for the deposit and dissemination of scientific research documents, whether they are published or not. The documents may come from teaching and research institutions in France or abroad, or from public or private research centers.
L'archive ouverte pluridisciplinaire HAL, est destinée au dépôt et à la diffusion de documents scientifiques de niveau recherche, publiés ou non, émanant des établissements d'enseignement et de recherche français ou étrangers, des laboratoires publics ou privés. 


\title{
Fishing for survival: The forgotten slaves of Tromelin Island (Indian Ocean) Philippe BÉAREZ and Laurie BOUFFANDEAU
}

\begin{abstract}
Between 2006 and 2013, the island of Tromelin (Indian Ocean) was surveyed and excavated within the framework of the UNESCO project "Forgotten Slaves".

Archaeozoological studies evidenced the survival behaviours and subsistence strategies implemented by the l'Utile shipwreck victims abandoned on the island between 1761 and 1776. The ichthyoarchaeological analysis of 4282 fish bones resulted in the identification of individuals belonging to 24 families of Teleostei and Chondrichthyes, among which Carangidae (jacks) largely dominate, followed by Serranidae (groupers), Acanthuridae (surgeonfishes), Balistidae (triggerfishes), Lutjanidae (snappers) and Pomacentridae (damselfishes). All of the cranial and postcranial elements were examined, and the taxonomic determination led to genus and species level attributions whenever possible. The composition of the assemblage, the ecology of the taxa, the nature of the nearby marine biotopes and the fishing gear unearthed on the site provided helpful data to characterise the probable fishing techniques used by the survivors. While line fishing along the drop-off and offshore with a craft might have been practiced widely by the Malagasy slaves, spearing and/or harpooning on the sandbank and coral reef, as well as hand gathering in the tidal pools off the reef flat surrounding the island, could have also strongly contributed to the overall catch. The results of this study reveal that this broad-spectrum exploitation of marine resources was opportunist, though it required skill and knowledge. They also shed light on the adaptation of the castaways to survive extreme conditions.
\end{abstract}

Keywords - Shipwreck, maritime archaeology, subsistence strategy, ichthyoarchaeology, fish

\section{1 | INTRODUCTION}

Very few wrecks of slave ships have been documented and even less have been subject to fieldwork (Webster, 2008). Shipwrecks on desolate and inhabited places are especially interesting to address human survival in extreme environments. However, shipwreck survivor camps are rarely investigated as testimonies of subsistence strategies (Gibbs, 2003). The availability of food and drink are key issues for the survivors' daily lives, and how people find these resources and live in places where survival is difficult are relevant questions to 
understand how humans are able to overcome the obstacles to survival. Moreover, a better understanding of the survival capacity of a human group on a small isolated island can provide useful information on the lifestyles and resilience of the first coastal inhabitants in a given area.

Several famous shipwrecks on tropical Indo-Pacific islands are known but little information is available concerning the daily subsistence of the survivors. For example, in 1629, the ship Batavia from the Dutch East India Company, with more than 300 people on board, was wrecked on the Houtman Abrolhos archipelago, $60 \mathrm{~km}$ from the Western Australian mainland (Green, 1975). Their search for drinking water is described but nothing is known about their fishing activities.

Maritime and shipwreck archaeology are even less developed in the western Indian Ocean (Lane, 2012). At Tromelin, we have a rare opportunity to document the marine resources exploited for survival on a small island by a relatively well-known number of people over a known period of time of 15 years.

On November 17, 1760, l'Utile, a cargo ship belonging to the French East India Company, departed from Bayonne, France, with 140 crew members, whose mission was to supply the colonies of the Indian Ocean (Guérout \& Romon, 2015). After their safe arrival at Mauritius Island, the ship was sent to Foulpointe, Madagascar, to bring back rice and beef. However, the captain decided to fraudulently embark 160 Malagasy slaves to be sold at Rodrigues Island before joining Mauritius. The ship, having deviated from its route, was shipwrecked during the night of July 31, 1761, on the edge of the Isle of Sands, today called Tromelin Island (Fig. 1). The $45 \mathrm{~m}$-long ship ran aground and broke over the coral reefs surrounding the deserted island; 70 slaves drowned locked in the hold, and 18 sailors were carried away by the stormy sea. The 210 survivors who reached the beach recovered any debris from the wreck, especially food and drink. Although they tried to organise themselves to survive, dehydration killed 8 further slaves before a well of brackish water was dug. Over the next two months, camps separating the slaves from the crew were set up, an oven and a forge were built, and the few available food resources on the island were exploited: birds, sea turtles and marine fishes. Faced with the lack of help, the French crew left Tromelin on September 27, 1761, aboard a makeshift boat, La Providence, built using debris from I'Utile. They abandoned 80 survivors on the island (Guérout, 2015), promising to return to seek them: the Malagasy slaves were to be trapped there for 15 years and many died. Guérout and Romon (2015: 112) consider that after three years, only 13 survivors occupied the island for the 12 remaining years. On November 29, 1776, the 8 remaining survivors, 7 women and a 7-month-old infant, were eventually rescued by the corvette la Dauphine under the 
command of lieutenant Jacques Marie Boudin de Tromelin and taken to Mauritius Island, where they were declared free (Guérout \& Romon, 2015).

Figure 1. Location of the main islands east of Madagascar within the southwestern Indian Ocean..

Today, Tromelin is classified as a nature reserve and part of the Scattered Islands, in the French Southern and Antarctic Lands. Since 1953, the island has hosted a meteorological station belonging to the cyclone warning network. It was during its construction that various remains and structures were unearthed. From 2003, the workers' testimonies as well as the historical written sources allowed Max Guérout (Groupe de Recherche en Archéologie Navale: GRAN) to shed light on this event (Guérout \& Romon, 2007). With the collaboration of Joe Guesnon (GRAN) and Thomas Romon (Institut National de Recherches Archéologiques Préventives: INRAP), terrestrial and underwater archaeological excavations were conducted in Tromelin in 2006, 2008, 2010 and 2013, as part of a project sponsored by the UNESCO project, 'Forgotten Slaves', documenting the slave trade in the Indian Ocean, particularly in Madagascar (Guérout \& Romon, 2007).

The archaeological study of Tromelin, the extreme conditions prevailing on the island and the peculiar human context related to the shipwreck of L'Utile, offers a rare opportunity to enrich our knowledge on the survival behaviours of the displaced Malagasy people and their ability to rapidly adapt to hostile conditions. The diet of the survivors relied almost exclusively on nesting green sea turtles and colonies of terns (Laroulandie \& Lefèvre, 2014 and unpublished data) and marine fishes. The aim of this ichthyoarchaeological study is to document the fish exploitation strategies implemented by the shipwrecked survivors. The quantification, the taxonomic identification of the fish remains and the analysis of their spatial distribution provided data that allowed us to characterise what part fish played in their diet and the fishing techniques they likely used.

\section{2 | CONTEXT}

Tromelin Island $\left(54^{\circ} 31^{\prime} \mathrm{E}, 15^{\circ} 53 \mathrm{~S}\right)$ is a small, oval coral island of about $1 \mathrm{~km}^{2}$, measuring $1500 \times 700 \mathrm{~m}$ (Fig. 2). It is composed of white sand, microdunes and scattered coral blocks surrounded by beach sandstone slabs and storm slopes. The highest point of the island is in the north and culminates at $8.5 \mathrm{~m}$ altitude (Marriner et al., 2010). The island of Tromelin is surrounded by a reef flat nearly $400 \mathrm{~m}$ wide, with furrows corresponding to tidal 
channels exposed at low tide and ending in a coral reef and a sandy outer slope. The foreshore area is subject to heavy surf, violent currents and breakers, especially on the south coast of the island (Marriner et al., 2012). The area is also affected by tropical disturbances and cyclones are common. Tromelin is swept by the prevailing trade winds and the swell can penetrate up to $250 \mathrm{~m}$ inside the island during the most intense storms. Palaeostorm levels are clearly visible in the sedimentary records: brutal cyclones cause the movement and spreading of sand, forming storm leashes. The layer associated with the 18th century's occupation has been preserved and sealed by a sterile level of storm deposit composed of beach sand (Guérout \& Romon, 2015).

Figure 2. Aerial view from the south of Tromelin Island (@ Richard Bouhet / AFP).

The vegetation of the island is very limited, and trees are absent. However, there are velvet shrubs (Tournefortia argentea), which can grow up to $2.5 \mathrm{~m}$ tall, herbaceous meadow (Boerhavia diffusa), which are subservient to microdunes, as well as purslane (Portulaca oleracea), and the Durand potato (Ipomoea pes-caprae). Almost no plant remains have been recovered at the site (M.-P. Ruas pers. comm.). Terrestrial fauna is also restricted (Paulian, 1955) but well represented in the archaeological records. Rare remains of small mammals and rats, and a pig canine, probably exogenous, have been discovered and are under analysis. Avifaunal remains are dominated by the sooty tern (Onychoprion fuscatus), which no longer breeds on the island, with noddy (Anous sp.), tropicbird (Phaethon sp.), booby (Sula sp.) and frigatebird (Fregata sp.) also represented in the assemblages (Laroulandie \& Lefèvre, 2014).

Marine archaeofauna unearthed on the site is much more diverse and consists of fishes, crustaceans, molluscs, including giant clams (Tridacna spp.), and green sea turtle (Chelonia mydas). Indeed, Tromelin is part of the Indo-Pacific biogeographic zone and is endowed with a rich marine biodiversity. Yet, scientific surveys and inventories for Tromelin are rare and its fish fauna is poorly known.

All of the post-shipwreck related areas were investigated during the four archaeological campaigns, including those on the beach, constituting the crews' and slaves' occupation zones during the first two months, and Site 5, called "High Point", in the north of the island (Fig. 3). Disturbances related to the construction of the meteorological station and the uncertain state of conservation of structures built by the slaves led to the implementation of emergency excavation strategies specific to preventive archaeology. Some areas have been opened with an excavator; others were searched by hand and sometimes screened. 
Figure 3. Layout of the excavation of Site 5.

The stratigraphy of the site, except in the sector where disturbances were recorded, was relatively clear and marked out by layers resulting from climatic phenomena (Marriner et al., 2010). The lithified storm deposit C5 is a non-anthropized layer, which lies on the coral substrate. It is in the $\mathrm{C} 4$ cultural level, corresponding to the occupation of the shipwreck survivors between 1761 and 1776 and divided into 3 sub-levels (C4a, b and c), that most of the remains have been uncovered. It is partly sealed with a storm level, called C3. Layer C2 constitutes a palaeosol posterior to the rescue of the slaves but anterior to construction of the meteorological station, between 1776 and 1950, sometimes disturbed in its lower part (C2b). Layer $\mathrm{C} 1$ is composed of the embankment resulting from the construction of the meteorological station, post-1950 (Guérout \& Romon, 2015: 146).

\section{3 | MATERIAL AND METHODS}

The totality of the 4282 Teleostei and Chondrichthyes bones studied here were unearthed in Site 5, between 2006 and 2013. These remains stem from sediments collected in sectors corresponding to the habitat of the Malagasy people after the departure of the French crew. The sediments were sieved through meshes of different sizes $(2,3$ and $5 \mathrm{~mm})$ according to the sectors and structures. These protocol differences did not allow for a spatial analysis. The fish bones were relatively well-preserved and with low rate of fragmentation; the sand layer which fixed the occupation level enabled good preservation by protecting the remains from climatic hazards. Several cut marks and burning traces were also observed on some remains and have been specified and recorded. All anatomical elements were considered in the analysis, cranial as well as post-cranial (Reitz \& Wing, 2008; Bouffandeau et al., 2018); however, no otoliths were found. Taxonomic identification, by morphological comparison was attributed to species level whenever possible, using the osteological reference collection housed at the National Museum of Natural History, Paris. This collection includes more than 850 Indo-Pacific fish specimens (ca 90 families, 220 genera, 475 species). Publications presenting regional ichthyofaunal lists (Terashima et al., 2001; Letourneur et al., 2004) were also necessary to guide the identifications and target local taxa within the rich Indo-Pacific biodiversity. 
The quantitative approach was based on counts and weights: the total Number of Remains (NR), composed of all identified or unidentified bone elements; the Number of Identified Specimens (NISP), and the Weight of Identified Specimens (WISP). The counts of the Minimum Numbers of Individuals (MNI) were performed by excavated units and then aggregated by levels. We used the MNI per combination (Poplin, 1976).

The body weight of each identified individual was visually estimated by comparison with the specimens available in the reference collection, in order to obtain average dimensions of the fishes composing the assemblage and refine the interpretations. By combining medium weight of individuals and $\mathrm{MNI}$ for each species we could roughly evaluate the total biomass of fish, from which we could obtain the edible biomass, by taking the $50 \%$ of the total weight (Torry Research Station, 1989).

The horizontal distribution of the fish remains in the levels was also examined, since it is likely to reveal potential functional areas and/or particular fish processing and consumption methods by the occupants of the site.

Finally, we took advantage of the many underwater photographs taken by the divers during the underwater prospections and excavations around the island. Most of the coral, benthic and pelagic fish taxa, visible on the photographs could be identified with the help of fish guides (Terashima et al., 2001; Taquet \& Diringer, 2012): surgeonfishes (Acanthuridae), triggerfishes (Balistidae), jacks (Carangidae), sharks (Carcharhinidae), butterflyfishes (Chaetodontidae), stingrays (Dasyatidae), wrasses (Labridae), snappers (Lutjanidae), moray eels (Muraenidae), angelfishes (Pomacanthidae), damselfishes (Pomacentridae) and groupers (Serranidae). In some instances these photographs helped us to be more confident with species attribution of fish bones, especially for large individuals of jack, snapper and triggerfish.

\section{4 | RESULTS}

\section{1| Assemblage composition}

Out of the 4282 studied fish remains, 889 were taxonomically identified (NISP), representing $1 / 5$ of the assemblage in terms of number of remains and $2 / 3(760 \mathrm{~g})$ of the total fish bone weight (Tab. 1). The MNI was estimated at 518. 
Table 1. List of taxa identified with their numbers of remains, MNI and bone weight.

The relatively low identification rate, despite good conservation, can be explained by the strong representation of non-diagnostic elements such as scales (NISP $=1326$ ), or fin elements such as spines and pterygiophores (Tab. 2). Vertebrae, whose identification is more challenging, were also present in significant number (NISP = 666). However, the fact that there is no perceptible imbalance between the number of cranial and postcranial elements, along with the occurrence of numerous scales, seems to indicate that the fish were brought back whole to the habitat zone and scaled on site.

Table 2. Distribution of fish skeletal parts.

The good preservation of fish bones enabled the reliable identification to species level in several cases (Tab. 1; Fig. 4). Among the identified taxa, a clear majority belong to the Teleostei or bony fish (Fig. 5), whereas Chondrichthyes, such as sharks (NISP $=3$ ) and rays $(\mathrm{NISP}=1)$ are poorly represented. The diversity within teleosts is important, since at least 22 families and 41 genera compose the assemblage. The modern species observed during the underwater prospections $(\mathrm{N}=62)$ correspond well to those identified in the archaeological material (Tab. 1; Tab. 3).

Figure 4. Some diagnostic fish bone remains from Site 5 of Tromelin : (A) precaudal vertebra of Caranx ignobilis; (B) precaudal vertebra of Epinephelus sp.; (C) caudal vertebra of Naso sp.; (D) precaudal and caudal vertebrae of Pomacentridae; $(E)$ caudal vertebrae of Bothus sp.; (F) right maxilla of Caranx ignobilis with cut marks; $(\mathrm{G})$ neural process of a caudal vertebra of Istiophorus platypterus; $(\mathrm{H})$ tooth of Balistoides viridescens; (I) dermal spine of Diodon hystrix; (J) dentary of Gymnothorax sp.; (K) right palatine of Lutjanus bohar, (L) epibranchial 4 of Scarus sp. - Scale bar $=1 \mathrm{~cm}$.

Figure 5. Main large species identified among the fish material and observed at Tromelin (from left to right and top to bottom): Caranx ignobilis; Caranx melampygus; Epinephelus tukula; Acanthurus lineatus; Balistoides viridescens; Lutjanus bohar. Copyright: Joël Mouret. 
Table 3. List of the 62 fish species observed at Tromelin based on underwater photos taken during underwater prospections.

Carangidae, or jacks, largely dominate the faunal spectrum (Fig. 6), in NISP (49\%), $\mathrm{MNI}(42 \%)$ and WISP (66\%). However, it is not surprising that these carnivorous pelagic fishes, frequently encountered around coastal reefs and oceanic islands, are well represented as they are a common prey of anglers. The diversity of the identified carangids is quite high (at least 7 species), although the genus Caranx dominates. Among this genus, many identified specimens exceed $10 \mathrm{~kg}$ and, in some cases, $20 \mathrm{~kg}$, which likely indicates the exploitation of giant trevallies (Caranx ignobilis), often found frequenting the drop-offs. Several blue jacks (Caranx melampygus), which usually swim along the shorelines, were also identified in the assemblage.

Figure 6. Distribution (NISP) of fish taxa from among the fish material from Tromelin site.

Within the assemblage, four other families represent more than $5 \%$ of the $\mathrm{MNI}$ : Serranidae, Acanthuridae, Balistidae and Lutjanidae. These taxa are usually connected with substrates close to the shore and can even be observed in surge zones, in particular surgeonfishes, such as Acanthurus lineatus. Several individuals of large dimensions were also noticeable in these families, especially the carnivorous ones. A few serranids in our sample reached nearly $30 \mathrm{~kg}$, most likely Epinephelus tukula (potato grouper); balistids weighed up to 4 or $5 \mathrm{~kg}$, like Balistoides viridescens (titan triggerfish); and some of the lutjanids, such as Lutjanus bohar (red dog snapper), weighed $7 \mathrm{~kg}$. It should also be noted that some large specimens occurred in more accessory families, such as parrotfishes, with Scarus ghobban at 7 to $8 \mathrm{~kg}$, or porcupinefishes, with Diodon hystrix at $3 \mathrm{~kg}$.

As for the rest of the identified fish, the sizes are variable but many show small dimensions, with weights ranging from a few dozen to a few hundred grams. Among these are reef-associated fishes, such as Pomacentridae (damselfishes), Chaetodontidae (butterfly fishes) and Bothidae (flatfishes).

Finally, it is interesting to mention the mysterious presence of two remains of what seems to be a sailfish (Istiophorus platypterus). The two remains, part of a rostrum and a fragment of caudal vertebra, are quite distant from each other (sectors 19 and 21) but could have belonged to the same individual. This large pelagic species is very combative, which raises questions as to its method of capture, especially as it weighed at least $50 \mathrm{~kg}$. The occurrence of this species in the vicinity of an oceanic island such as Tromelin, where depths of $1000 \mathrm{~m}$ are attained at only $2.5 \mathrm{~km}$ from the island's coastline (Marriner et al., 2010), is 
easily conceivable. However, it is highly unlikely that an individual just washed up on shore, and it is more probable that it was harpooned in open water because it often swims near the surface, showing its sail.

Considering the estimated weights and MNI, the total fish biomass could be approximately $1000-1200 \mathrm{~kg}$, which constitutes an edible biomass of about $500-600 \mathrm{~kg}$.

\subsection{Stratigraphic and spatial distribution}

In all structures where the same stratigraphy could be found, most of the fish bones were concentrated in the $\mathrm{C} 4$ layer, which yielded $74 \%$ of the identified remains. Another $12 \%$ of the NISP stem from layer C2b. The remaining 14\% were recovered from the sector S21TR1312. In all cases, Carangidae (jacks) dominate with a NISP between $47 \%$ and $64 \%$, and the order of the main families remains unchanged: Carangidae, Serranidae, Acanthuridae, Balistidae, Lutjanidae. As expected for larger sample sizes, taxonomic diversity is higher in layer $\mathrm{C} 4$, which also shows the largest number of remains. However, a different pattern is visible in sector S21-TR1312: the proportion of jacks is the highest but only a restricted number of large-sized individuals are present (i.e. 2 specimens of big-head trevallies, weighing respectively $12 \mathrm{~kg}$ and $18 \mathrm{~kg}$ ). Remarkably, this sector yielded solely cranial elements but no vertebrae. One of the two remains of sailfish, a fragment of rostrum bearing burning traces, was also uncovered in this area. Could it have been a disposal zone for nonvaluable fish parts?

The quantitative distribution of remains per sector (Tab. 4; Fig. 3) offers little information, due to the sieving parameters not being homogeneous. For example, sectors 17 to 21 , excavated in 2013 , were sieved by means of a smaller mesh size than the other ones, which could explain why they yielded an important number of remains. It is, however, noticeable that sector 17 provided the largest NR for the whole of Site 5, with a total of 1487 remains, out of which 1482 belong to layer C4 (NISP = 232 or $27 \%$ ). The other structures that yielded significant numbers of remains (> 5\%) are, in descending order of importance: S19, S21, S06, S15, S11 and S20. All of them are outlying sectors: does this indicate a disposal pattern, or a choice by the occupants to keep the central area of their habitat clean?

Table 4. Distribution of fish remains by sector.

\section{5 | DISCUSSION}


Given the total number of fish remains found in the excavations (NR $=4282$ ), it appears that fish were not the primary source of protein for the castaways, but that birds and sea turtles also played an important role (Laroulandie \& Lefèvre, 2014 and unpublished data). However, these figures must be put into perspective by considering the large sizes of some of these fishes: a grouper of at least $30 \mathrm{~kg}$, jacks of 20 to $25 \mathrm{~kg}$, and snappers and parrotfishes of about $10 \mathrm{~kg}$, as well as one or two sailfishes of about $50 \mathrm{~kg}$. Considering the estimated weights and MNI, the total fish biomass could be approximately $1000-1200 \mathrm{~kg}$, which constitutes an edible biomass of about $500-600 \mathrm{~kg}$. If we consider that only 13 survivors occupied the island for 12 years (Guérout \& Romon, 2015), that would mean ca 3.5 $\mathrm{kg}$ of fish flesh per person per year, which is certainly not a negligible amount within the diet of the castaways.

The capture of these big fishes would have required venturing out to the open sea and, for carnivorous specimens, to fish using lines and hooks. Indeed, four hooks from sector S03 and a spear tip from sector S19, were found, attesting to angling and harpooning activities (Fig. 7).

But although building a craft to go fishing during calm sea days might have been possible the shipwrecked people could have taken advantage of the debris of the wreck or driftwood stranded on the shore for its construction - it would still have been necessary to overcome their probable apprehension of the ocean.

Figure 7. Fishing artefacts, fishhooks (T08.PH5.272 \& T08.PH5.273) and spear point (T13.PH5.1035), recovered during the excavation of the Tromelin site. Scale bar $=1 \mathrm{~cm}$

Angling is the most likely technique for the capture of several carnivorous species present in the studied material, such as jacks, groupers and snappers. The occurrence of the latter species, Lutjanus bohar (see Fig. 3), is also mentioned in the logbook attributed to Hilarion Dubuisson de Keraudic, the ship's official log keeper (M. Guérout pers. comm.): "Nous avons pris deux grandes sardes". The term "sardes" probably corresponds to the name given to snappers in the Caribbean (Cuvier \& Valenciennes, 1828: 440) where some of the crew members might have worked previously; its relationship with bonitos (Sarda spp.) seems less likely.

The fishing of small-size fishes could have been practiced along the shore in calm weather, taking advantage of the low tide and tidal pools; indeed, some of the small reef fishes identified in the assemblage might have been captured by hand in these intertidal pools. 
The origin of the slaves is not known with certainty; thus, it is difficult to define if they were accustomed to the marine environment and fishing. However, anthropologists suggest, after analysis of the strontium and barium of two skeletons uncovered at the site, that they possibly originated from Madagascar - the highlands for one individual, and the coastal zone for the second (Guérout \& Romon, 2015). It is therefore likely that those among the Malagasy people or the French sailors who knew how to fish transmitted their knowledge and techniques to the entire group during the first two months. On this permanently swept coast fishing is opportunistic, as it is often the case in extreme situations and environments. It appears that selection by size or specific distinctions were not made during the capture of the fish and all accessible biotopes seem to have been exploited. The survivors showed an amazing ability to adapt, which is also visible in the use of raw materials and reuse of objects recovered from the wreckage.

\section{6 | CONCLUSION}

This study allows us to glimpse aspects of the life of the slaves on a remote and desolate island. At the same time, this example illustrates the importance of such studies for the understanding of the ability of humans to adapt and survive to complex conditions in hostile environments.

The ichthyoarchaeological data provides insight into the use of marine resources through fishing on a desolated island. It reveals that ichthyological resources also played a key role in the subsistence of the Malagasy shipwreck survivors on Tromelin, besides those of sea turtles and birds. And although one would have expected that fish, a permanent resource, would have played a major role in their diet, access to this rough sea from a small island with almost no reef flat, by people that were, at least at the beginning of their stay, probably little experienced as mariners, would have been difficult. In this sense, shipwreck archaeology has much to contribute to the understanding of behavioural adaptation to survival and, beyond that, to the exploitation of marine resources by human groups during dispersal along coastal routes.

\section{Acknowledgements}

We would like to thank Max Guérout and Thomas Romon for giving us the opportunity to study the fish bone material, as well as Véronique Laroulandie for involving us in this project. Special thanks are also due to Joel Mouret for authorising us to utilise his underwater pictures taken at Tromelin. Thanks to Jill Cucchi for copy-editing, and to the anonymous reviewers for their valuable comments. 
ORCID
Philippe Béarez http://orcid.org/0000-0003-0397-2393

\section{References}

Bouffandeau, L., Béarez, P., Bedford, S., Valentin, F., Spriggs, S., \& Nolet, E. (2018). Fishing at Arapus-Mangaasi, Efate, Vanuatu (2800-2200 BP): New methodological approaches and results. Journal of Archaeological Science: Reports, 18, 356-369.

Cuvier, G., \& Valenciennes, A. (1828). Histoire naturelle des poissons. Tome second. Livre Troisième. Des poissons de la famille des perches, ou des percoïdes, 1-490. Paris: Levrault.

Gibbs, M. (2003). The archaeology of crisis: Shipwreck survivor camps in Australasia. Historical Archaeology, 37(1), 128-145.

Green, J. (1975). The VOC ship Batavia wrecked in 1629 on the Houtman Abrolhos, Western Australia. The International Journal of Nautical Archaeology and Underwater Exploration, 4, 43-63.

Guérout, M. (2015). Tromelin. Mémoire d'une île. CNRS Éditions, Paris, 278 p.

Guérout, M., Romon, T. (2007). Tromelin (Océan Indien). Les Nouvelles de l'archéologie, 108/109, 113-118.

Guérout M., \& Romon, T. (2015). Tromelin. L'île aux esclaves oubliés. CNRS Éditions / INRAP, Paris, $233 \mathrm{p}$.

Lane, P.J. (2012). Maritime and shipwreck archaeology in the western Indian Ocean and southern Red Sea: An overview of past and current research. Journal of Maritime Archaeology, 7(1), 9-41.

Laroulandie, V., \& Lefèvre, C. (2014). The use of avian resources by the forgotten slaves of Tromelin Island (Indian Ocean). International Journal of Osteoarchaeology, 24, 407-416.

Letourneur, Y., Chabanet, P., Durville, P., Taquet, M., Teissier, E., Parmentier, M., Quéro, J.C., \& Pothin, K. (2004). An updated checklist of the marine fish fauna of Reunion Island, South-western Indian Ocean. Cybium, 28(3), 199-216.

Marriner, N., Guérout, M., \& Romon, T. (2010). The forgotten slaves of Tromelin (Indian Ocean): New geoarchaeological data. Journal of Archaeological Science, 37(6), 1293-1304.

Marriner, N., Pirazzoli, P.A., Fontugne, M., Guérout, M., Guillaume, M., \& Reyss, J.L. (2012). A geomorphological reconnaissance of Tromelin Island, Indian Ocean, Journal of Coastal Research, 28(6), 1606-1616. 
Paulian, R. (1955). Observations sur la faune terrestre de l'île Tromelin. Le Naturaliste Malgache, 7(1), 1-7.

Poplin, F. (1976). Remarques théoriques et pratiques sur les unités utilisées dans les études d'ostéologie quantitative, particulièrement en archéologie préhistorique. IXth UISPP Congress, Nice, Thèmes spécialisés, $B$, Problèmes ethnographiques des vestiges osseux, pp. 124-141.

Reitz, E.J., \& Wing, E.S. (2008). Zooarchaeology. Cambridge: Cambridge University Press, $533 \mathrm{p}$.

Taquet, M., \& Diringer, A. (2012). Poissons de l'océan Indien et de la mer Rouge. Versailles: Éditions Quae, 680 p.

Terashima, H., Mosaheb, J.I., Paupiah, C.N., Chineah, V. (2001). Field guide to coastal fishes of Mauritius. Albion: AFRC, $191 \mathrm{p}$.

Torry Research Station, Aberdeen, Scotland, UK (1989). Yield and nutritional value of the commercially more important fish species. FAO Fisheries Technical Paper, 309. Rome: FAO, $187 \mathrm{p}$.

Webster, J. (2008). Slave ships and maritime archaeology: An overview. International Journal of Historical Archaeology, 12(1), 6-19. 

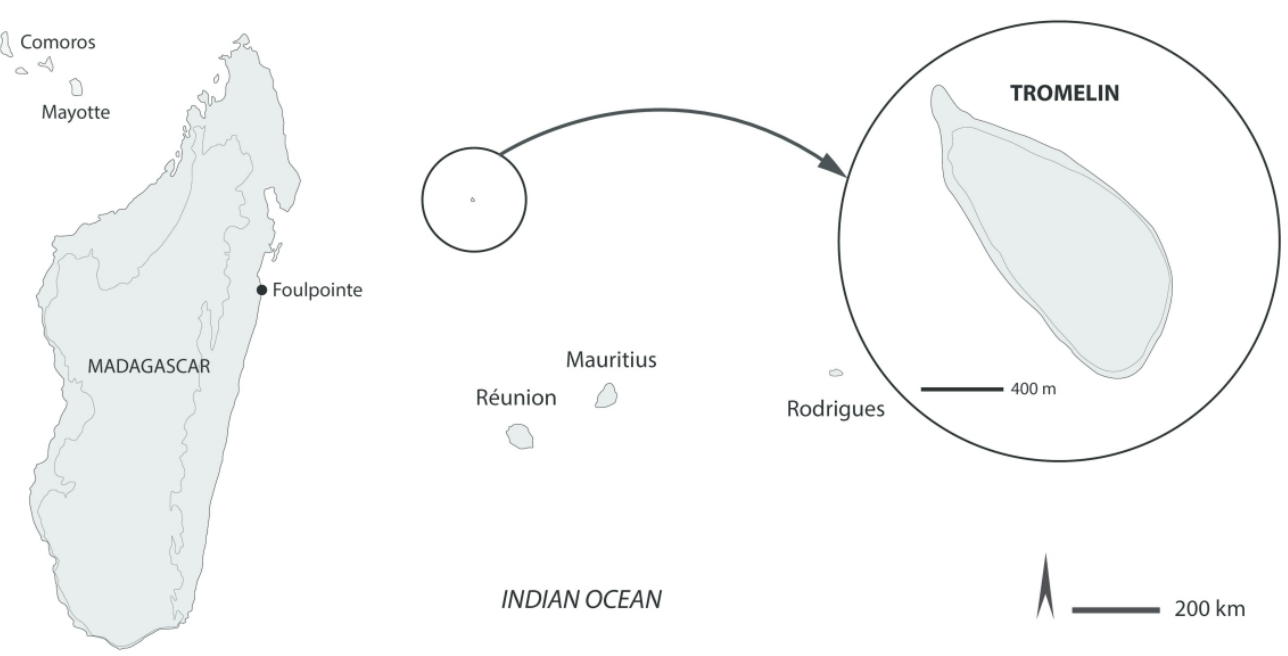

Figure 1: Location of the main islands east of Madagascar within the southwestern Indian Ocean.

$413 \times 204 \mathrm{~mm}(300 \times 300$ DPI $)$ 


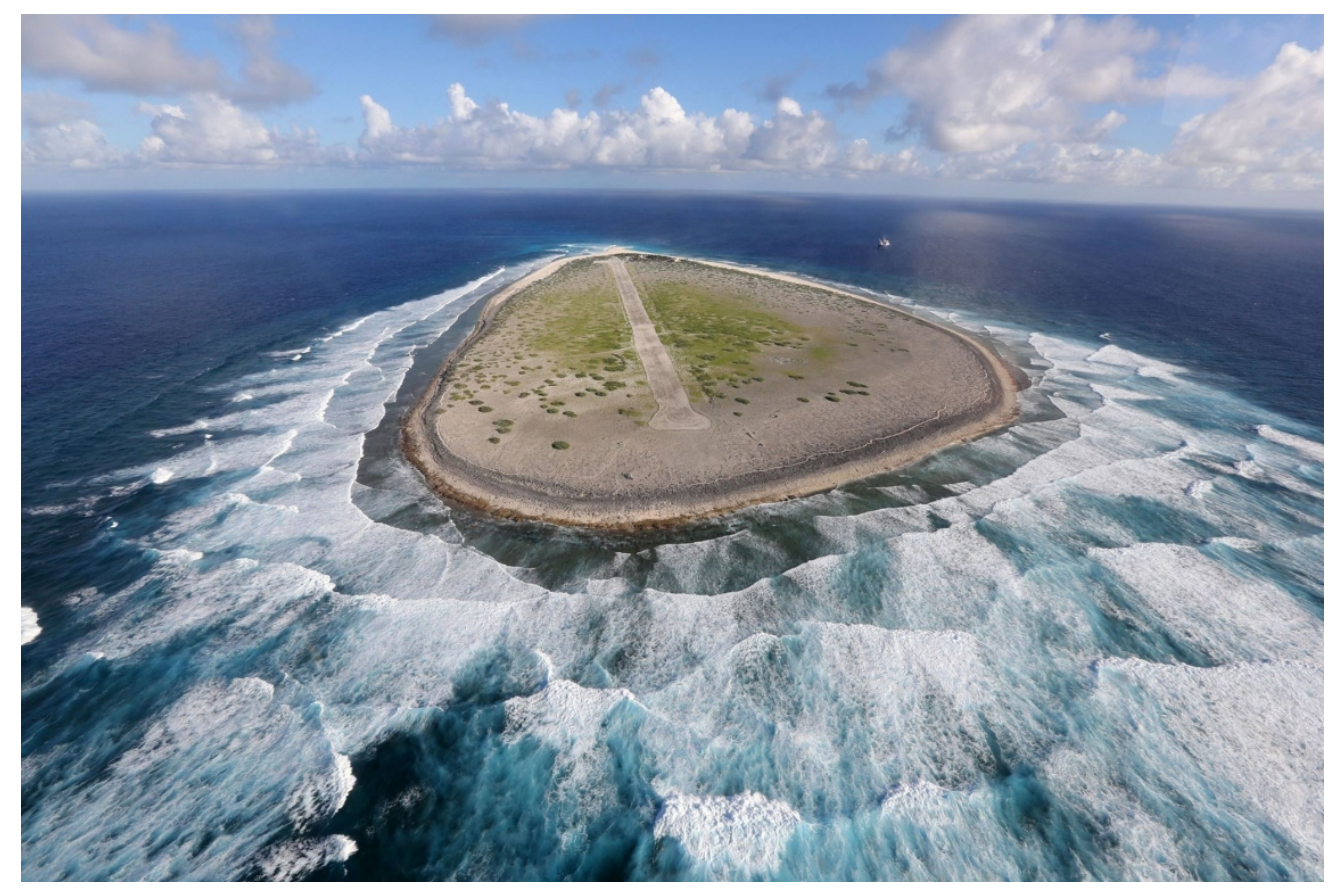

Figure 2: Aerial view from the south of Tromelin Island (@ Richard Bouhet / AFP). $722 \times 481 \mathrm{~mm}(72 \times 72 \mathrm{DPI})$ 


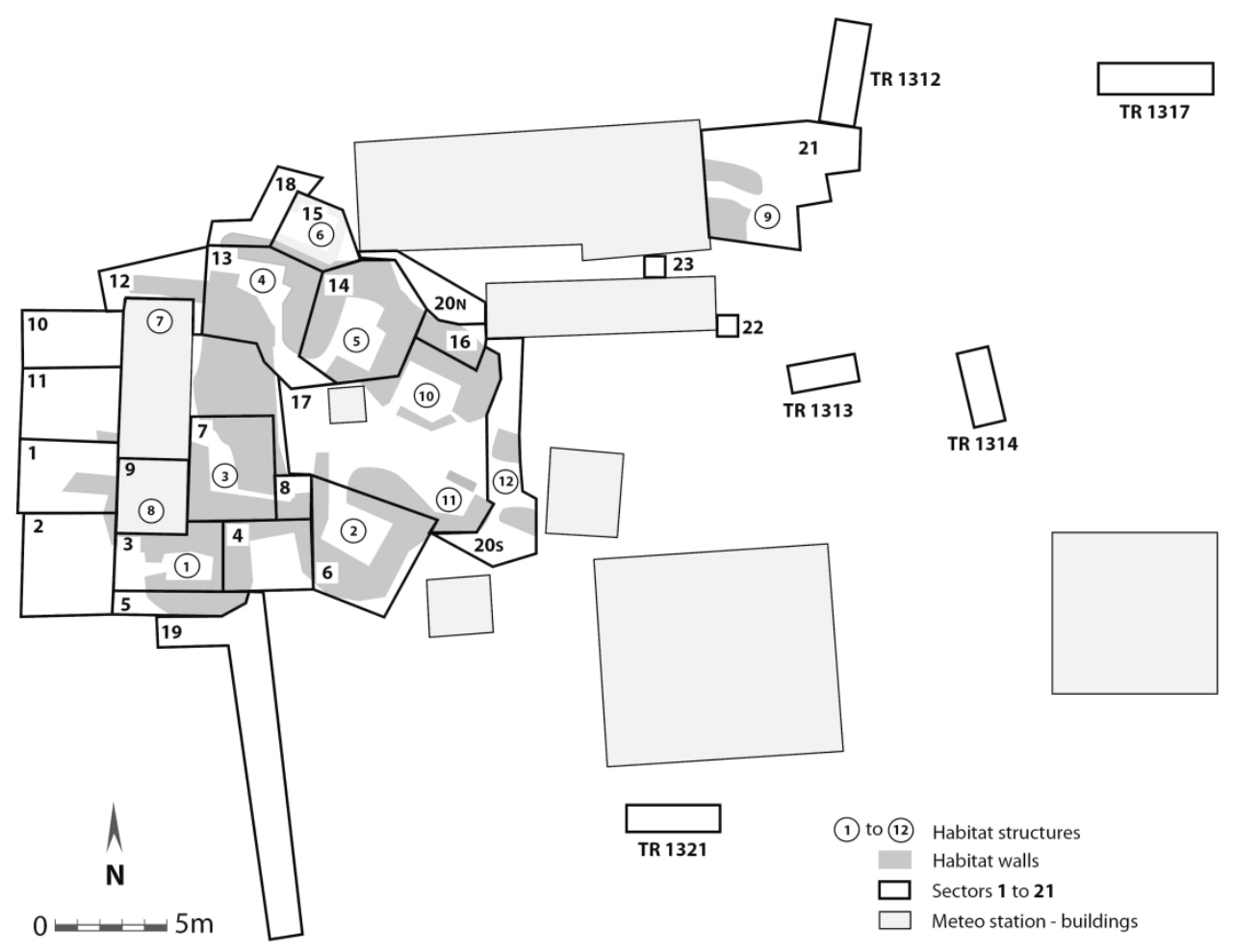

Figure 3: Layout of the excavation of Site 5.

$312 \times 241 \mathrm{~mm}(300 \times 300$ DPI $)$ 


\begin{tabular}{|c|c|c|c|c|c|c|c|}
\hline Taxa & NISP & MNI & WISP (g) & Thalassoma spp. & $\begin{array}{l}1 \\
4\end{array}$ & $\begin{array}{l}1 \\
3\end{array}$ & $\begin{array}{l}0.30 \\
0.49\end{array}$ \\
\hline \multicolumn{4}{|l|}{ CARANGIDAE } & \multicolumn{4}{|l|}{ BOTHIDAE } \\
\hline Caranx ignobilis & 86 & 25 & 334.12 & Bothus spp. & 13 & 7 & 1.73 \\
\hline Caranx melampygus & 83 & 56 & 47.32 & & & & \\
\hline Caranx sexfasciatus & 2 & 2 & 1.53 & SCARIDAE & & & \\
\hline Caranx spp. & 70 & 54 & 70.31 & Scarus ghobban & 4 & 4 & 11.49 \\
\hline Trachinotus baillonii & 10 & 10 & 1.86 & Scarus spp. & 6 & 6 & 12.27 \\
\hline Trachinotus blochii & 8 & 5 & 1.56 & Chlorurus cf. sordidus & 1 & 1 & 0.05 \\
\hline Trachinotus cf. africanus & 1 & 1 & 0.13 & gen. sp. & 1 & 1 & 0.06 \\
\hline Trachinotus spp. & 55 & 27 & 11.54 & & & & \\
\hline Elagatis bipinnulata & 4 & 3 & 0.61 & DIODONTIDAE & & & \\
\hline Carangoides cf. fulvoguttatus & 1 & 1 & 0.07 & Diodon hystrix & 2 & 2 & 2.81 \\
\hline gen. sp. & 116 & 34 & 33.25 & Diodon spp. & 6 & 6 & 2.15 \\
\hline \multicolumn{4}{|l|}{ SERRANIDAE } & gen. sp. & 2 & 2 & 0.36 \\
\hline Epinephelus spp. & 75 & 40 & 52.95 & \multicolumn{4}{|l|}{ HOLOCENTRIDAE } \\
\hline Cephalopholis cf. argus & 1 & 1 & 0.29 & Sargocentron spp. & 3 & 3 & 1.40 \\
\hline Cephalopholis spp. & 15 & 12 & 1.55 & gen. sp. & 1 & 1 & 0.06 \\
\hline gen. sp. & 5 & 5 & 3.58 & \multicolumn{4}{|l|}{ ANGUILLIFORMES } \\
\hline \multicolumn{4}{|l|}{ ACANTHURIDAE } & gen. sp. & 4 & 3 & 0.26 \\
\hline Acanthurus xanthopterus & 3 & 3 & 2.24 & \multirow{2}{*}{\multicolumn{4}{|c|}{ EXOCOETIDAE }} \\
\hline Acanthurus triostegus & 2 & 2 & 0.12 & & & & \\
\hline Acanthurus lineatus & 2 & 1 & 0.99 & gen. sp. & 3 & 3 & 0.15 \\
\hline Acanthurus spp. & 49 & 38 & 14.73 & \multicolumn{4}{|l|}{ LETHRINIDAE } \\
\hline Naso spp. & 22 & 8 & 13.17 & gen. sp. & 3 & 2 & 0.23 \\
\hline Ctenochaetus spp. & 3 & 3 & 0.34 & & & & \\
\hline Zebrasoma spp. & 2 & 1 & 0.06 & \multicolumn{4}{|l|}{ ISTIOPHORIDAE } \\
\hline gen. sp. & 12 & 8 & 1.07 & Istiophorus platypterus & 2 & 2 & 10.94 \\
\hline BALISTIDAE & & & & \multicolumn{4}{|l|}{ BELONIDAE } \\
\hline Balistoides viridescens & 13 & 7 & 31.06 & Tylosurus cf. crocodilus & 2 & 2 & 0.11 \\
\hline Sufflamen spp. & 3 & 3 & 0.28 & & & & \\
\hline gen. sp. & 50 & 20 & 9.09 & \multicolumn{4}{|l|}{ CHAETODONTIDAE } \\
\hline \multicolumn{4}{|l|}{ LUTJANIDAE } & \multirow{2}{*}{$\begin{array}{l}\text { Chaetodon spp. } \\
\text { gen. sp. }\end{array}$} & \multirow{3}{*}{$\begin{array}{l}1 \\
1\end{array}$} & \multirow{3}{*}{$\begin{array}{l}1 \\
1\end{array}$} & \multirow{3}{*}{$\begin{array}{l}0.06 \\
0.01\end{array}$} \\
\hline Lutjanus bohar & 4 & 4 & 3.12 & & & & \\
\hline Lutjanus spp. & 30 & 22 & 42.96 & GERREIDAE & & & \\
\hline gen. sp. & 3 & 3 & 4.98 & gen. sp. & 2 & 1 & 0.10 \\
\hline \multicolumn{4}{|l|}{ POMACENTRIDAE } & \multicolumn{4}{|l|}{ HEMIRAMPHIDAE } \\
\hline \multirow{2}{*}{$\begin{array}{l}\text { Abudefduf spp. } \\
\text { gen. sp. }\end{array}$} & 9 & 4 & 1.05 & \multirow{2}{*}{$\begin{array}{l}\text { gen. sp. } \\
\text { POMACANTHIDAE }\end{array}$} & 2 & 1 & 0.03 \\
\hline & 24 & 16 & 3.82 & & & & \\
\hline KYPHOSIDAE & & & & Pomacanthus spp. & 1 & 1 & 0.21 \\
\hline Kyphosus vaigiensis & 8 & 7 & 2.33 & & & & \\
\hline Kyphosus cf. bigibbus & 3 & 3 & 1.78 & Total TELEOSTEI & 885 & 516 & 759.62 \\
\hline Kyphosus spp. & 15 & 12 & 7.87 & CARCHARHINIDAE & & & \\
\hline MURAENIDAE & & & & gen. sp. & 3 & 1 & 0.31 \\
\hline Gymnothorax spp. & 12 & 8 & 7.13 & DASYATIDAF & & & \\
\hline gen. sp. & 8 & 6 & 4.64 & gen. sp. & 1 & 1 & 0.15 \\
\hline LABRIDAE & & & & & & & \\
\hline Coris spp. & 6 & 3 & 0.39 & Total CHONDRICHTHYES & 4 & 2 & 0.46 \\
\hline Cheilinus spp. & 4 & 3 & 0.29 & TOTAL & 889 & 518 & 760.07 \\
\hline Thalassoma purpureum & 1 & 1 & 0.22 & & & & \\
\hline
\end{tabular}


Table 2

\begin{tabular}{|c|c|c|c|c|c|}
\hline BONE & NISP & WISP (g) & BONE & NISP & WISP (g) \\
\hline scale & 1326 & 34.54 & parasphenoid & 8 & 15.01 \\
\hline $\begin{array}{l}\text { unidentified } \\
\text { fragment }\end{array}$ & 906 & 213.99 & basioccipital & 8 & 4.87 \\
\hline spine & 863 & 156.29 & urostyle & 8 & 4.15 \\
\hline vertebra & 666 & 416.29 & scapula & 7 & 2.18 \\
\hline pterygiophore & 61 & 23.81 & supracleithrum & 5 & 3.75 \\
\hline scute & 46 & 14.59 & $\begin{array}{l}\text { posterior } \\
\text { ceratohyal }\end{array}$ & 4 & 1.91 \\
\hline preopercle & 39 & 24.71 & ectopterygoid & 3 & 2.55 \\
\hline cleithrum & 35 & 25.41 & epibranchial & 3 & 2.49 \\
\hline hyomandibula & 33 & 18.38 & subopercle & 3 & 1.09 \\
\hline dentary & 31 & 40.00 & $\begin{array}{l}\text { neurocranial } \\
\text { bone }\end{array}$ & 2 & 4.48 \\
\hline opercle & 31 & 15.95 & glossohyal & 2 & 0.57 \\
\hline premaxilla & 28 & 31.96 & urohyal & 2 & 0.17 \\
\hline maxilla & 26 & 42.88 & rostrum & 1 & 1.98 \\
\hline quadrate & 24 & 9.86 & supraoccipital & 1 & 0.70 \\
\hline anguloarticular & 21 & 35.69 & basipterygoid & 1 & 0.51 \\
\hline pharyngeal bone & 18 & 17.46 & metapterygoid & 1 & 0.22 \\
\hline posttemporal & 17 & 5.83 & postcleithrum & 1 & 0.17 \\
\hline anterior ceratohyal & 16 & 2.27 & tail spine & 1 & 0.15 \\
\hline palatine & 12 & 7.91 & |lacrymal & 1 & 0.06 \\
\hline tooth & 11 & 2.41 & hypural plate & 1 & 0.05 \\
\hline vomer & 9 & 8.35 & TOTAL & 4282 & 1195.62 \\
\hline
\end{tabular}


Table 3

\section{Family}

Acanthuridae

Acanthuridae

Acanthuridae

Acanthuridae

Acanthuridae

Acanthuridae

Acanthuridae

Acanthuridae

Acanthuridae

Acanthuridae

Balistidae

Balistidae

Belonidae

Carangidae

Carangidae

Carangidae

Carangidae

Carangidae

Carangidae

Carcharhinidae

Carcharhinidae

Carcharhinidae

Chaetodontidae

Chaetodontidae

Chaetodontidae

Chaetodontidae

Dasyatidae

Diodontidae

Holocentridae

Labridae

Labridae

Labridae

Labridae

Labridae

Labridae

Labridae

Lethrinidae

Lutjanidae

Lutjanidae

Lutjanidae

Lutjanidae

Lutjanidae

Mullidae

Muraenidae

Muraenidae

Pomacanthidae

Pomacentridae

Pomacentridae

Pomacentridae

\section{Genus}

Acanthurus

Acanthurus

Acanthurus

Acanthurus

Ctenochaetus

Naso

Naso

Naso

Naso

Zebrasoma

Balistoides

Melichthys

Tylosurus

Carangoides

Caranx

Caranx

Caranx

Caranx

Trachinotus

Carcharhinus

Carcharhinus

Triaenodon

Chaetodon

Chaetodon

Chaetodon

Heniochus

Himantura

Diodon

Myripristis

Gomphosus

Halichoeres

Labroides

Thalassoma

Thalassoma

Thalassoma

Thalassoma

Monotaxis

Aprion

Lutjanus

Lutjanus

Lutjanus

Macolor

Parupeneus

Gymnothorax

Gymnothorax

Pomacanthus

Abudefduf

Chromis

Chromis
Species

nigricauda

leucosternon

lineatus

triostegus

truncatus

brevirostris

elegans

tuberosus

unicornis

desjardinii

viridescens

niger

crocodilus

orthogrammus

ignobilis

lugubris

melampygus

sexfasciatus

baillonii

albimarginatus

falciformis

obesus

guttatissimus

lunula

meyeri

acuminatus

cf. $f a i$

hystrix

sp.

caeruleus

hortulanus

dimidiatus

amblycephalum

hardwicke

hebraicum

trilobatum

grandoculis

virescens

bohar

fulviflamma

kasmira

niger

trifasciatus

favagineus

sp.

imperator

vaigiensis

dimidiata

nigrura

\section{Common name}

Epaulette surgeonfish

Powderblue surgeonfish

Lined surgeonfish

Convict surgeonfish

Yelloweye bristle-tooth

Spotted unicornfish

Elegant unicornfish

Humpnose unicornfish

Bluespine unicornfish

Indian sail-fin surgeonfish

Titan triggerfish

Black triggerfish

Hound needlefish

Island trevally

Giant trevally

Black jack

Bluefin trevally

Bigeye trevally

Small spotted dart

Silvertip shark

Silky shark

Whitetip reef shark

Peppered butterflyfish

Raccoon butterflyfish

Scrawled butterflyfish

Pennant coralfish

Pink whipray

Spot-fin porcupinefish

Soldierfish

Green birdmouth wrasse

Checkerboard wrasse

Bluestreak cleaner wrasse

Bluntheaded wrasse

Sixbar wrasse

Goldbar wrasse

Christmas wrasse

Humpnose big-eye bream

Green jobfish

Two-spot red snapper

Dory snapper

Common bluestripe snapper

Black and white snapper

Doublebar goatfish

Laced moray

Moray

Emperor angelfish

Indo-Pacific sergeant

Chocolatedip chromis

Blacktail chromis 


$\begin{array}{llll}\text { Priacanthidae } & \text { Myripristis } & \text { sp. } & \text { Soldierfish } \\ \text { Scaridae } & \text { Chlorurus } & \text { strongylocephalus } & \text { Steephead parrotfish } \\ \text { Scaridae } & \text { Hipposcarus } & \text { harid } & \text { Candelamoa parrotfish } \\ \text { Scaridae } & \text { Scarus } & \text { caudofasciatus } & \text { Redbarred parrotfish } \\ \text { Scaridae } & \text { Scarus } & \text { rubroviolaceus } & \text { Ember parrotfish } \\ \text { Scombridae } & \text { Gymnosarda } & \text { unicolor } & \text { Dogtooth tuna } \\ \text { Serranidae } & \text { Epinephelus } & \text { tauvina } & \text { Greasy grouper } \\ \text { Serranidae } & \text { Epinephelus } & \text { tukula } & \text { Potato grouper } \\ \text { Serranidae } & \text { Pseudanthias } & \text { evansi } & \text { Yellowback anthias } \\ \text { Serranidae } & \text { Variola } & \text { louti } & \text { Yellow-edged lyretail } \\ \text { Sphyraenidae } & \text { Sphyraena } & \text { barracuda } & \text { Great barracuda } \\ \text { Synodontidae } & \text { Synodus } & \text { variegatus } & \text { Variegated lizardfish } \\ \text { Zanclidae } & \text { Zanclus } & \text { cornutus } & \text { Moorish idol }\end{array}$


Table 4

\begin{tabular}{|l|r|r|}
\hline \multicolumn{1}{|c|}{ SECTOR } & NISP & \multicolumn{1}{|c|}{ WISP $(\mathbf{g})$} \\
\hline S01 & 29 & 12.45 \\
S02 & 18 & 5.31 \\
S03 & 53 & 3.00 \\
S06 & 467 & 79.29 \\
S07 & 65 & 16.09 \\
S10 & 51 & 2.82 \\
S11 & 231 & 24.37 \\
S12 & 75 & 8.05 \\
S13 & 46 & 3.76 \\
S14 & 77 & 22.25 \\
S15 & 313 & 84.53 \\
S17 & 1487 & 178.16 \\
S18 & 16 & 72.84 \\
S19 & 509 & 106.91 \\
S20 & 218 & 86.08 \\
S21 & 490 & 454.00 \\
TR1306 & 94 & 22.70 \\
TR1312 & 23 & 3.12 \\
TR1315 & 20 & 9.90 \\
\hline TOTAL & 4282 & 1195.62 \\
\hline
\end{tabular}

36

37

38

39

40

41

42

43

44

45

46

47

48

49

50

51

52

53

54

55

56

57

58

59

60

http://mc.manuscriptcentral.com/oa 

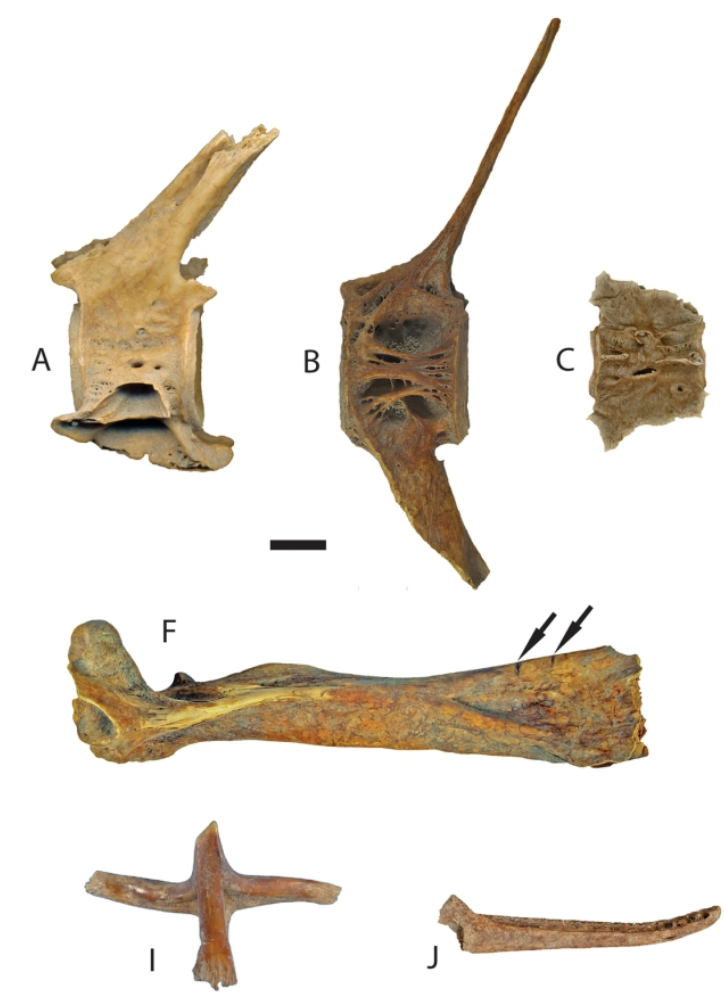

$E \stackrel{A}{A}$

D
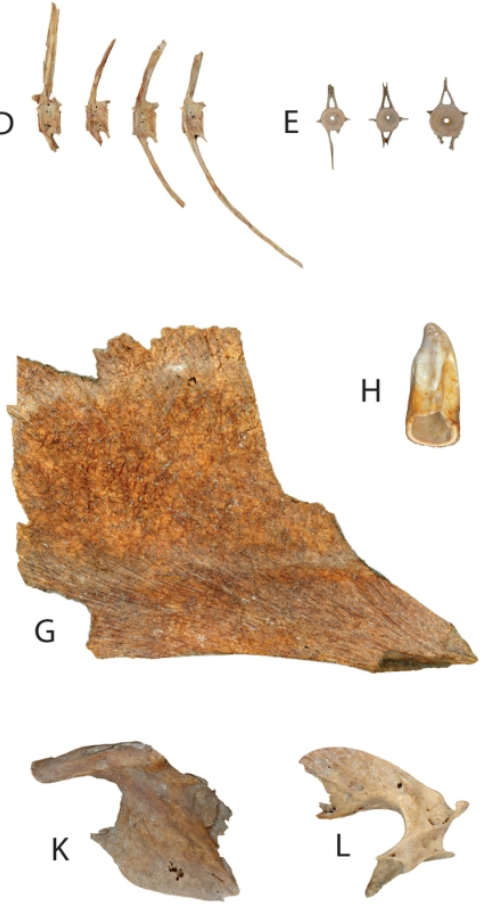

Figure 4. Some diagnostic fish bone remains from Site 5 of Tromelin : (A) precaudal vertebra of Caranx ignobilis; (B) precaudal vertebra of Epinephelus sp.; (C) caudal vertebra of Naso sp.; (D) precaudal and caudal vertebrae of Pomacentridae; (E) caudal vertebrae of Bothus sp.; (F) right maxilla of Caranx ignobilis with cut marks; $(G)$ neural process of a caudal vertebra of Istiophorus platypterus; $(H)$ tooth of Balistoides viridescens; (I) dermal spine of Diodon hystrix; (J) dentary of Gymnothorax sp.; (K) right palatine of Lutjanus bohar; $(L)$ epibranchial 4 of Scarus sp. - Scale bar $=1 \mathrm{~cm}$.

$169 \times 129 \mathrm{~mm}(300 \times 300 \mathrm{DPI})$ 
Figure 5. Main large species identified among the fish material and observed at Tromelin (from left to right and top to bottom): Caranx ignobilis; Caranx melampygus; Epinephelus tukula; Acanthurus lineatus; Balistoides viridescens; Lutjanus bohar. (ㄷ Joël Mouret)

$160 \times 181 \mathrm{~mm}(300 \times 300 \mathrm{DPI})$ 


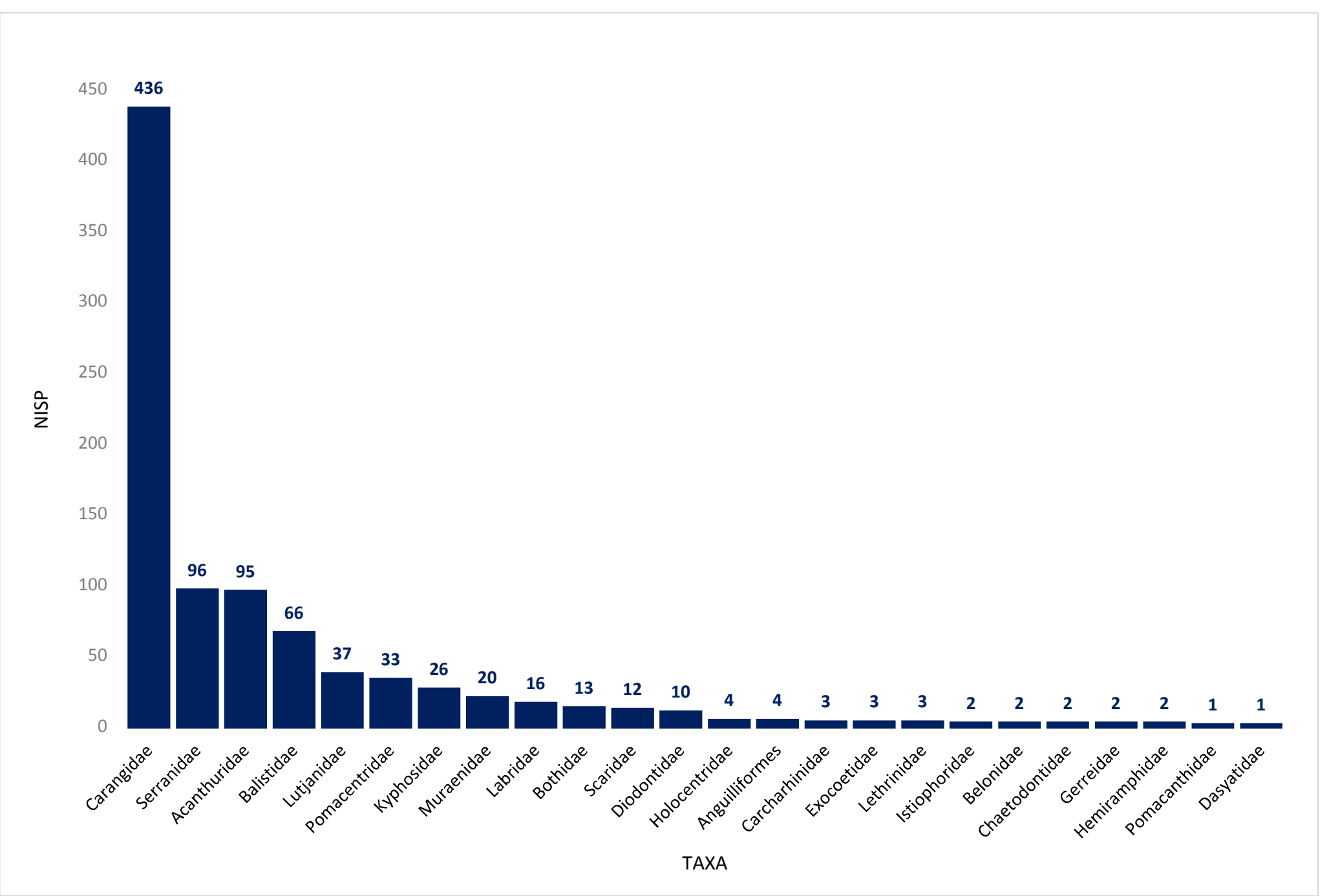


8
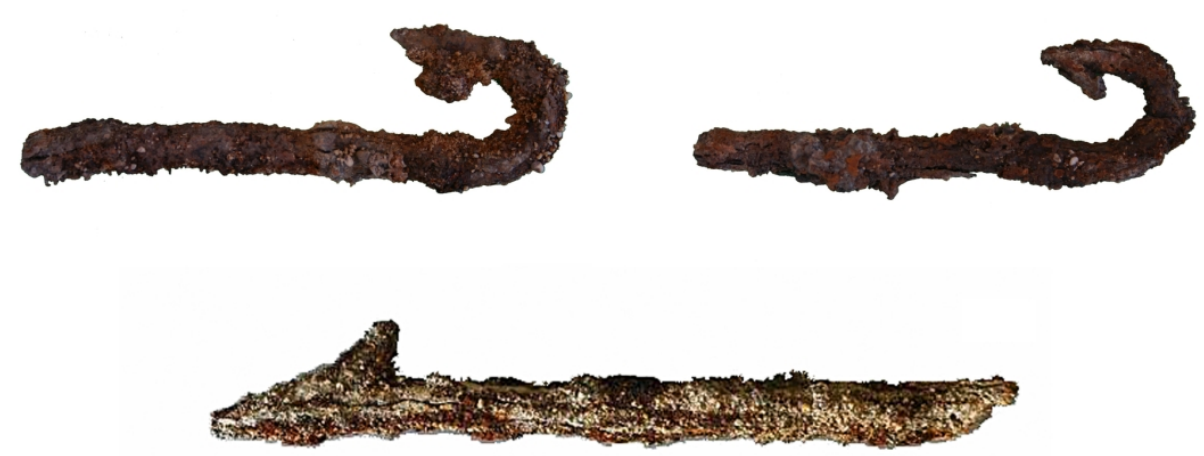

Figure 7. Fishing artefacts, fishhooks (T08.PH5.272 \& T08.PH5.273) and spear point (T13.PH5.1035), recovered during the excavation of the Tromelin site. Scale bar $=1 \mathrm{~cm}$ 